\title{
AURKB Gene
}

National Cancer Institute

\section{Source}

National Cancer Institute. AURKB Gene. NCI Thesaurus. Code C68592.

This gene is involved in mitosis and meiosis. 